\title{
Metabolic Acidosis Stimulates Protein Degradation in Rat Muscle by a Glucocorticoid-dependent Mechanism
}

R. C. May, R. A. Kelly, and W. E. Mitch

Department of Medicine, Harvard Medical School and the Brigham and Women's Hospital, Boston, Massachusetts 02115

\begin{abstract}
Metabolic acidosis is associated with enhanced renal ammoniagenesis which is regulated, in part, by glucocorticoids. The interaction between glucocorticoids and chronic metabolic acidosis on nitrogen utilization and muscle protein metabolism is unknown. In rats pair-fed by gavage, we found that chronic acidosis stunted growth and caused a $43 \%$ increase in urinary nitrogen and an $87 \%$ increase in urinary corticosterone. Net protein degradation in incubated epitrochlearis muscles from chronically acidotic rats was stimulated at all concentrations of insulin from 0 to $10^{4} \mu \mathrm{U} / \mathrm{ml}$. This effect of acidosis persisted despite supplementation of the media with amino acids with or without insulin, indomethacin, and inhibitors of lysosomal thiol cathepsins. Acidosis did not change protein synthesis; hence, the increase in net protein degradation was caused by stimulation of proteolysis. Acidosis did not increase glutamine production in muscle. The protein catabolic effect of acidosis required glucocorticoids; protein degradation was stimulated in muscle of acidotic, adrenalectomized rats only if they were treated with dexamethasone. Moreover, when nonacidotic animals were given $3 \mu \mathrm{g} / 100 \mathrm{~g}$ of body weight dexamethasone twice a day, muscle protein degradation was increased if the muscles were simply incubated in acidified media. We conclude that chronic metabolic acidosis depresses nitrogen utilization and increases glucocorticoid production. The combination of increased glucocorticoids and acidosis stimulates muscle proteolysis but does not affect protein synthesis. These changes in muscle protein metabolism may play a role in the defense against acidosis by providing amino acid nitrogen to support the glutamine production necessary for renal ammoniagenesis.
\end{abstract}

\section{Introduction}

In humans and experimental animals, the response to metabolic acidosis is characterized by an increase in urinary ammonia coupled to a rise in plasma glutamine extraction by the kidney. Whether this response results in increased urinary nitrogen excretion and by implication, negative nitrogen balance, is less clear. A decline in urea production proportionate to the increase in urinary ammonium during acidosis could serve to minimize nitrogen excretion and thereby preserve nitrogen stores. Certain observations suggest that this does not occur. When fasted rats are fed hydrochloric acid, there is no change in their urea ex-

This work was published as an abstract (1985. Clin. Res. 33:572). Address reprint requests to Dr. Mitch. 1985.

Received for publication 23 May 1985 and in revised form 3 October

J. Clin. Invest.

(c) The American Society for Clinical Investigation, Inc.

$0021-9738 / 86 / 02 / 0614 / 08 \quad \$ 1.00$

Volume 77, February 1986, 614-621 cretion despite a fourfold rise in urinary ammonia (1). In humans, correction of the acidosis associated with starvation or chronic renal failure suppresses, rather than augments, urea production $(2,3)$. If urea production is not diminished by acidosis, the nitrogen required for renal ammoniagenesis must be supplied by increased protein catabolism. The improved growth of children with renal tubular acidosis following alkali therapy suggests that acidosis does impair overall nitrogen utilization (4). A catabolic response to acidosis is likely to involve skeletal muscle, the major repository of protein, but it is unknown whether metabolic acidosis increases protein degradation (PD) ${ }^{1}$ or inhibits protein synthesis (PS) in muscles of fed animals. Most studies of the effect of acidosis on muscle nitrogen metabolism have focused on glutamine release but have not found an increased release consistently (5-9). Moreover, glutamine release is a poor marker of muscle protein turnover because it is synthesized in muscle $(10,11)$.

In addition to any direct effect of acidosis on protein turnover, there are humoral factors that could interact with acidosis to alter protein metabolism. For example, plasma corticosterone levels are high in chronically acidotic rats (12) and glucocorticoids suppress PS and may stimulate PD in muscle (13-17). Acidosis also increases urinary prostaglandin $\mathrm{E}_{2}\left(\mathrm{PGE}_{2}\right)$ in rats (18), an eicosanoid known to increase muscle PD in vitro $(19,20)$.

To clarify the effect of metabolic acidosis on nitrogen utilization and muscle protein metabolism, we measured rates of growth, total nitrogen excretion and net urea production in chronically acidotic rats. We also measured rates of protein synthesis and degradation in muscles of these rats and assessed the role of potential mediators of altered muscle protein turnover.

\section{Methods}

Animals. Male Sprague-Dawley rats weighing 125-150 g (Charles River Breeding Laboratory, Inc., Wilmington, MA) were used in all studies. Four studies (studies I-IV) were performed. The rats were housed in a temperature-controlled room with a 12-h light-12-h dark cycle and given water and RMH 1000 pellets (Agway Country Foods, Syracuse, NY) containing $14 \%$ protein ad libitum. Over a 3 - to 4 -d period, gavage feeding was substituted for the pellets. The gavage-fed diet contained $12 \mathrm{~g} / \mathrm{d}$ of dry chow, consisting, by weight, of $14 \%$ casein (Vita-Free Micropulverized Casein, U. S. Biochemicals, Cleveland, $\mathrm{OH}$ ), $72 \%$ of a mixture of corn starch and sucrose (5:4 wt/wt), 7\% corn oil, $2 \%$ vitamins (ICN Nutritional Biochemicals, Cleveland, $\mathrm{OH}$ ), and $5 \%$ mineral salts. The diet was mixed $(1.67: 1, \mathrm{wt} / \mathrm{vol})$ with water or a solution of ammonium chloride $\left(\mathrm{NH}_{4} \mathrm{Cl}\right)$ to provide $4 \mathrm{mmol} / 100 \mathrm{~g}$ of body weight per day ( $\sim 25 \%$ of nitrogen intake) and given by gavage in two equal portions at 9 a.m. and 6 p.m. for $5 \mathrm{~d}$; the $\mathrm{NH}_{4} \mathrm{Cl}$ group also was given $0.25 \mathrm{M} \mathrm{NH}_{4} \mathrm{Cl}$ to drink ad libitum while the control rats drank water (study I). On the evening preceding the experiment, acidotic and control rats were fed only the acid load or the equivalent volume of water to reduce the variability associated with differences in absorption of food.

1. Abbreviations used in this paper: ADX, adrenalectomized; PCA, perchloric acid; PD, protein degradation; PS, protein synthesis. 
In study II, the effects of acidosis were separated from those of feeding ammonium. The dry laboratory diet was mixed with an equimolar amount of $\mathrm{HCl}, \mathrm{NH}_{4} \mathrm{Cl}$, or ammonium acetate, and rats gavage-fed these diets were compared to rats fed the diet mixed in water; all were given water to drink.

In study III, rats weighing $75-100 \mathrm{~g}$ were adrenalectomized through a dorsal incision and were fed RMH 1000 diet and given $0.154 \mathrm{M}$ saline to drink ad libitum for a period of 10-20 d before they were randomly assigned to one of three groups: adrenalectomy (ADX) without supplementation (group A); ADX with low-dose dexamethasone $(0.6 \mu \mathrm{g} / 100$ g weight, twice daily subcutaneously) (group B); ADX with high-dose dexamethasone $(3.0 \mu \mathrm{g} / 100 \mathrm{~g}$ weight, twice daily subcutaneously) (group C). The low dose of dexamethasone for group B rats was based on the endogenous secretory rate of corticosterone in rats $(21,22)$, assuming a relative dexamethasone to corticosterone potency ratio of 265:1 (23). The dose for group $\mathrm{C}$ rats was chosen to correspond to the plasma corticosterone levels of stressed rats $(17,22)$. Rats of groups A-C were gavagefed using a protocol identical to study $I$, except that they were given $0.154 \mathrm{M} \mathrm{NaCl}$ to drink, potassium was deleted from the diet, and for group $\mathrm{A}$, the acid load was reduced to $3 \mathrm{mmol} / 100 \mathrm{~g}$ of body weight to prevent excessive mortality $(22,24)$.

In study IV, the effects of prostaglandin synthesis inhibitors were studied. Rats were gavage-fed as in study I, except that control and acidotic rats received $3 \mathrm{mg}$ indomethacin $/ \mathrm{kg}$ orally twice daily. With this dose, plasma indomethacin is $\geq 3 \mu \mathrm{M}$, a level that inhibits prostaglandin production in rat muscle without causing hepatic injury or toxic accumulation of the drug $(25,26)$.

In vivo studies. In study II, net urea nitrogen production and urinary nitrogen excretion of rats gavage-fed $\mathrm{NH}_{4} \mathrm{Cl}$ or an equimolar amount of ammonium acetate were compared. Rats were placed in individual metabolic cages and urine was collected in acidified containers during days 3 and 4 of the protocol; total nitrogen was measured by the Kjeldahl method (27). At the beginning and end of the collection period, rats were weighed and tail vein blood was obtained in order to calculate the urea appearance rate (28).

Hindquarter perfusion. The technique for perfusing the hindquarter of anesthetized ( $5 \mathrm{mg}$ pentobarbitol/100 $\mathrm{g}$ of body weight; i.p.) rats was similar to that described previously $(29,30)$, and is based on the technique of Ruderman et al. (31). Perfusates of $150 \mathrm{ml}$ of aged, washed human erythrocytes, hematocrit $25 \%$, in Krebs-Henseleit buffer, prefiltered albumin (final concentration $3 \mathrm{~g} / \mathrm{dl}$ ), $10 \mathrm{mM}$ glucose, amino acids in concentrations found in rat plasma, and $0.5 \mathrm{mM}$ cycloheximide were prepared before each experiment. The $\mathrm{pH}$ of perfusate was altered by changing the bicarbonate concentration from 25 to $10 \mathrm{mM}$. Aliquots of media were obtained at 30 and $90 \mathrm{~min}$, and the rate of release of tyrosine was measured from changes in its concentration and the volume of perfusate. Total PD, expressed per gram of muscle perfused, was calculated using relationships between body weight and muscle perfused established previously (28).

Epitrochlearis muscle incubation. Epitrochlearis muscles from anesthetized rats were removed, blotted, weighed, and incubated in flasks containing $3 \mathrm{ml}$ of modified Krebs-Henseleit buffer (13.5 mM bicarbonate) and $10 \mathrm{mM}$ glucose which had been thoroughly gassed with $95 \%$ $\mathrm{O}_{2} / 5 \% \mathrm{CO}_{2}$ (32). Unless specified, muscles of acidotic rats were incubated in pH 7.15 media, because this was the average $\mathrm{pH}$ of their arterial blood (Table I). Muscles of control rats were incubated at $\mathrm{pH} 7.40$ in unmodified buffer plus $10 \mathrm{mM}$ glucose. After a 30-min preincubation, muscles were removed, blotted, and transferred to flasks containing $3 \mathrm{ml}$ of identical media plus fatty acid and globulin-free albumin $(0.2 \mathrm{~g} / \mathrm{dl})$ and varying concentrations of insulin as indicated. The albumin was omitted when insulin was not present to avoid any contaminating insulinlike activity contained in the albumin. The flasks were stoppered and regassed for 3 min and then incubated for $2 \mathrm{~h}$. At the end of $2 \mathrm{~h}$, the muscles were removed, blotted, and immediately homogenized in either $1.0 \mathrm{ml}$ icecold trichloroacetic acid (TCA) to measure tyrosine and phenylalanine $(33,34)$ or $1 \mathrm{ml} 10 \%$ perchloric acid (PCA) to measure glutamine, glutamate (35), and tissue ATP and creatine phosphate content $(36,37)$. Phenylalanine and tyrosine also were measured in the incubation media.
Table I. Effects of Chronic Metabolic Acidosis on Nitrogen Excretion and Urea Appearance

\begin{tabular}{llll}
\hline & Blood pH & $\begin{array}{l}\text { Urea N } \\
\text { appearance }\end{array}$ & $\begin{array}{l}\text { Urinary } \\
\text { nitrogen }\end{array}$ \\
\hline & & $m g N / 100 g$ & $m g N / 100 g$ \\
& & $48 h$ & $48 h$ \\
Control & $7.37 \pm 0.01$ & $106.7 \pm 6.3$ & $176.3 \pm 11.0$ \\
Acidotic & $7.14 \pm 0.01^{*}$ & $96.7 \pm 12.9$ & $252.1 \pm 7.8^{*}$ \\
\hline
\end{tabular}

Values are means \pm standard error of the mean for at least seven rats in each group. Control rats were gavage-fed a diet containing $4 \mathrm{mmol}$ ammonium acetate $/ 100 \mathrm{~g}$ per day while acidotic rats received an equimolar amount of ammonium chloride.

* $P<0.001$ by unpaired $t$ test compared to control.

During incubation in the standard media, we found no increase in glutamine production by acidotic muscles, but tissue glutamate levels were found to be low and this could have been rate-limiting for glutamine synthesis. Thus, the experiment was repeated with media supplemented with amino acids (except for tyrosine and glutamine) and ammonium chloride at the concentrations found in rat plasma (38). With the supplemented media, muscle glutamate in acidotic and control rats $(0.665 \pm 0.023 \mathrm{nmol} / \mathrm{mg}$ of wet weight for acidotic vs. $0.714 \pm 0.022 \mathrm{nmol} /$ $\mathrm{mg}$ of wet weight for control) did not differ and remained constant during the incubation. One muscle was homogenized in $1 \mathrm{ml}$ of iced $10 \%$ PCA after the 30-min preincubation period, and the intracellular glutamine concentration was measured. After the $2-\mathrm{h}$ incubation period, the contralateral muscle was homogenized in $1 \mathrm{ml}$ of iced $10 \%$ PCA, and the intracellular glutamine content and glutamine release into the media were measured. The net rate of glutamine production was calculated as the change in muscle glutamine content during the incubation period plus the amount of glutamine released in the media.

In study IV, $3 \mu \mathrm{M}$ indomethacin was included in the media since this concentration inhibits prostaglandin production by muscle (26). The importance of lysosomal cathepsins in mediating muscle proteolysis was studied by incubating with $25 \mu \mathrm{M}$ EP475, an inhibitor of lysosomal cathepsins B, H, and L (39). We have found that $25 \mu \mathrm{M}$ EP475 inhibits cathepsin B activity by $95 \%$ in incubated epitrochlearis muscles (26).

Analytical procedures. In study I, 24-h urine specimens were centrifuged at $2,000 \mathrm{~g}$ for $10 \mathrm{~min}$ to remove particulate material and the supernatants were stored at $-70^{\circ} \mathrm{C}$. Urinary corticosterone was extracted into methylene chloride using $\left[{ }^{3} \mathrm{H}\right]$ corticosterone as an internal standard. Each sample was applied to a disposable $\mathrm{C}_{18}$ cartridge (Sep-Pak; Waters Associates, Millipore Corp., Milford, MA) and then consecutively washed with $10 \mathrm{ml}$ of water and $2 \mathrm{ml}$ of $20 \%$ acetonitrile/water (vol/vol) before elution with $100 \%$ acetonitrile; the flow rate was $0.5 \mathrm{ml} / \mathrm{min}$. The eluate was dried under nitrogen and reconstituted in $1 \mathrm{ml}$ of $0.1 \mathrm{M}$ Tris- $\mathrm{Cl}(\mathrm{pH}$ 7.4); recovery was $92 \pm 4 \%$ (mean \pm standard deviation). The corticosterone concentration in the reconstituted urine samples was measured using a radioimmunoassay kit (Cambridge Medical Diagnostics; Billerica, MA). $50 \mu \mathrm{l}$ of each extract were mixed with ${ }^{125} \mathrm{I}$-corticosterone and sheep anticorticosterone antiserum and incubated overnight at $4^{\circ} \mathrm{C}$; rabbit $\gamma$ globulin was added as a nonspecific carrier protein. Goat anti- $\gamma$-globulin was added the following morning and allowed to incubate for $1 \mathrm{~h}$ at $22^{\circ} \mathrm{C}$. $1 \mathrm{ml}$ of saline was added and the samples were centrifuged at $2,000 \mathrm{~g}$ for $15 \mathrm{~min}$ before the radioactivity in the pellet (bound ${ }^{125} \mathrm{I}$ corticosterone) was determined. Standard curves were constructed in urine from ADX rats. The sensitivity of the assay was approximately 50 $\mathrm{pg} / \mathrm{ml}$. The primary antibody had the following crossreactivities with other endogenous steroids: progesterone, $4.0 \%$; 11-desoxycorticosterone, 2.5\%; aldosterone, $2.0 \%$; testosterone, $1.8 \%$; androstenedione, $1.4 \%, 17$ $\beta$-estradiol, $<0.01 \%$; estrone, $<0.01 \%$; cholesterol, $<0.01 \%$.

The $\mathrm{pH}$ of aortic blood was measured on an Instrumentation Laboratory Inc. (Lexington, MA) model 313 pH/blood gas analyzer. Net 
PD was calculated from the rate of release of tyrosine into the media, because tyrosine (like phenylalanine) is neither synthesized nor degraded in muscle and because we found that $\leq 6 \%$ of tyrosine release could be attributed to changes in intracellular tyrosine in muscles of either control or acidotic rats. PS was determined during a $2-\mathrm{h}$ incubation by measuring the incorporation of $\mathrm{L}-\left[\mathrm{U}-{ }^{14} \mathrm{C}\right]$ phenylalanine $(0.05 \mu \mathrm{Ci} / \mathrm{ml})$ into muscle protein when $0.5 \mathrm{mM}$ phenylalanine was added to the media to minimize the reincorporation of the label. The intracellular specific radioactivity of phenylalanine in muscles of control and acidotic rats was found to be equal to that in the media after $30 \mathrm{~min}$ as reported previously (29). Consequently, the incorporation of $\mathrm{L}-\left[\mathrm{U}-{ }^{14} \mathrm{C}\right]$ phenylalanine into muscle protein was divided by the specific radioactivity of phenylalanine in the media to calculate the rate of PS.

Materials. $\mathrm{L}-\left[\mathrm{U}-{ }^{14} \mathrm{C}\right]$ phenylalanine was obtained from Swartz-Mann (Dickinson and Company, Orange, NY), $\left[{ }^{3} \mathrm{H}\right]$ corticosterone from New England Nuclear (Boston, MA) and reagent grade chemicals were purchased from Fisher Scientific Company (Pittsburgh, PA). All enzymes, except for urease (U. S. Biochemical, Cleveland, OH), NAD, NADPH fatty acid, and globulin-free albumin, indomethacin, and cycloheximide were purchased from Sigma Chemical Co. (St. Louis, MO). Dexamethasone and purified porcine insulin were purchased from Elkins-Sinn Inc. (Cherry Hill, NJ) and Eli Lilly \& Company (Indianapolis, IN), respectively. The lysosomal cathepsin inhibitor, EP475, was kindly donated by Dr. A. L. Goldberg, Harvard Medical School, Boston, MA.

Statistics. Results are presented as mean \pm standard error of the mean and were compared using the paired and unpaired Student's $t$ test and analysis of variance. Results were considered significant at $P<0.05$.

\section{Results}

Long-term studies of rats being pair-fed by gavage indicated that chronic metabolic acidosis impaired growth (Figure 1). Compared to initial weights, rats fed $\mathrm{NH}_{4} \mathrm{Cl}$ had gained significantly less weight than nonacidotic rats fed the same diet without $\mathrm{NH}_{4} \mathrm{Cl}$ $(+37 \pm 5 \mathrm{~g}$, acid vs. $+55 \pm 3 \mathrm{~g}$, control; $P<0.01)$. This suggests that metabolic acidosis impairs nitrogen utilization.

To assess the effects of acidosis on nitrogen metabolism, urinary nitrogen and the urea appearance rate were measured in study II. Because rats were fed an equimolar amount of $\mathrm{NH}_{4} \mathrm{Cl}$ or ammonium acetate, this study permitted us to distinguish between the effects of ammonium and the resulting acidosis.

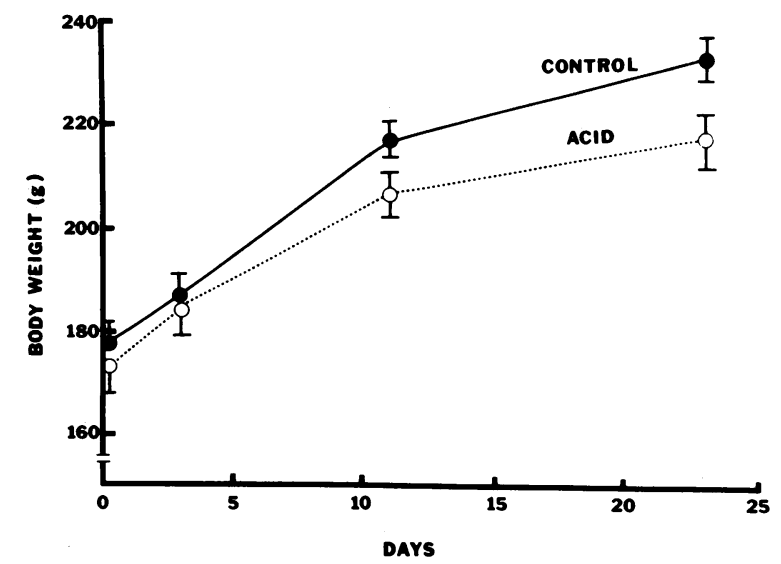

Figure 1. The change in weight of rats gavage-fed diets identical in protein and calorie content. Compared to initial weights, rats receiving $4 \mathrm{mmol} \mathrm{NH}{ }_{4} \mathrm{Cl} / 100 \mathrm{~g}$ of body weight per day gained significantly less weight $(P<0.05)$ than the nonacidotic, control group. Values shown are mean \pm standard error of the mean.
The acidotic rats ( $\mathrm{pH} 7.14 \pm 0.01$ ) had a $43 \%$ increase in urinary nitrogen despite an identical nitrogen intake (Table I). Although fecal nitrogen was not measured, it seems unlikely that the higher nitrogen excretion by acidotic rats was due to differences in nitrogen absorption in that none of the rats had diarrhea. Chronic metabolic acidosis did not increase urea production (Table I), in agreement with other reports (40). Because the urinary ammonium of $\mathrm{NH}_{4} \mathrm{Cl}$-treated rats is substantially higher than that of rats treated with equimolar ammonium bicarbonate (40), it is likely that the increased urinary nitrogen (Table I) was due to ammonium. These results (Fig. 1; Table I) indicate that nitrogen utilization is markedly impaired by chronic metabolic acidosis.

In vitro studies. To study the effects of an acute $\mathrm{pH}$ change on muscle proteolysis, the isolated hindquarter of normal rats was perfused with pH 7.0-7.2 media. Proteolysis was unaffected by acute acidosis $(137.6 \pm 7.5 \mathrm{nmol}$ of $\mathrm{Tyr} / \mathrm{g} \cdot \mathrm{h}, \mathrm{pH} 7.15$ media vs. $138.0 \pm 6.0 \mathrm{nmol}$ of $\mathrm{Tyr} / \mathrm{g} \cdot \mathrm{h}, \mathrm{pH} 7.4 \mathrm{media})$. This was confirmed when epitrochlearis muscles from normal rats were incubated at pH 7.15 with $10^{2}$ or $10^{3} \mu \mathrm{U} / \mathrm{ml}$ of insulin. Net PD in these muscles incubated in acid was not different from that of contralateral muscles incubated at pH 7.40 (Table II). This effect of acidosis could not be attributed to impaired viability of the incubated muscles (Table III). The values of ATP and creatine phosphate content were similar to those we have measured previously in incubated epitrochlearis muscle and in insitu freeze-clamped skeletal muscle $(11,41)$.

In contrast, net PD was significantly increased in muscles from chronically-acidotic rats both in the absence of insulin and at all concentrations of insulin studied (Fig. 2). The abnormal net PD was not corrected by incubating muscles in pH 7.4 media and persisted when the incubation media was supplemented with insulin and amino acids at concentrations found in normal rat plasma (38) (Table II).

To determine whether the higher rate of net PD in muscles of acidotic rats was due to inhibition of PS, this was measured both with and without $10^{4} \mu \mathrm{U} / \mathrm{ml}$ insulin. PS did not differ between acidotic and control rats $(44 \pm 2.4$, acid vs. $44.0 \pm 2.1 \mathrm{nmol}$ $\mathrm{Phe} / \mathrm{g} \cdot \mathrm{h}$, control without insulin; $60.0 \pm 1.8$, acid vs. $65.4 \pm 4.4$ $\mathrm{nmol} \mathrm{Phe} / \mathrm{g} \cdot \mathrm{h}$ control at $10^{4} \mu \mathrm{U} / \mathrm{ml}$ of insulin). Thus, the increase in net PD was due to stimulation of muscle PD.

To examine whether this catabolic effect was due to ammonium, two separate controls were studied. Although net PD in rats treated with $\mathrm{HCl}$ was stimulated to a lesser extent than by treatment with $\mathrm{NH}_{4} \mathrm{Cl}$, all acidotic rats had a significantly higher rate of muscle proteolysis compared to control rats (Table IV). The arterial blood $\mathrm{pH}$ of rats receiving ammonium acetate was 7.36 \pm 0.01 , and net PD in their muscles was not different statistically from that of control rats (Table IV). Thus, the stimulatory effect of $\mathrm{NH}_{4} \mathrm{Cl}$ on muscle proteolysis was due, at least indirectly, to the metabolic acidosis and not to any independent effect of ammonium.

To determine whether the catabolic effect of acidosis requires lysosomal proteolysis, an inhibitor of lysosomal thiol proteases, EP475, was used. A concentration of $25 \mu \mathrm{M}$ EP475 reduces cathepsin B activity by $95 \%$ in incubated epitrochlearis muscles (26). Muscles from $\mathrm{NH}_{4} \mathrm{Cl}$-treated rats had a higher rate of net PD than control rats, both in the presence and absence of EP475; net PD was reduced by a small and comparable degree in muscles from both groups (Table V), suggesting that the proteolytic effect of chronic acidosis primarily involves nonlysosomal pathways.

The possibility that stimulated prostaglandin synthesis mediates the accelerated proteolysis of metabolic acidosis was stud- 
Table II. Influence of pH, Amino Acid, and Insulin Supplementation of the Media and Indomethacin Treatment on Net Protein Degradation in Incubated Muscles

\begin{tabular}{|c|c|c|c|c|}
\hline \multirow[b]{2}{*}{ Treatment } & \multirow[b]{2}{*}{ Incubation condition } & \multicolumn{3}{|c|}{ Net protein degradation } \\
\hline & & pH 7.15 media & pH 7.40 media & \% Change \\
\hline & & \multicolumn{3}{|c|}{ nmol tyrosine/g per $h$} \\
\hline \multirow[t]{2}{*}{ Untreated (6) } & $10^{2} \mu \mathrm{U} / \mathrm{ml}$ insulin & $112.3 \pm 4.8$ & $117.8 \pm 5.6$ & $4.2 \pm 5.0$ \\
\hline & $10^{4} \mu \mathrm{U} / \mathrm{ml}$ insulin & $83.4 \pm 1.6$ & $85.6 \pm 5.8$ & $1.0 \pm 5.8$ \\
\hline Chronic acidosis (6) & No additions & $174.1 \pm 12.4$ & $179.1 \pm 9.7$ & $3.1 \pm 2.0$ \\
\hline \multirow[t]{2}{*}{ Untreated (6) } & Amino acids & & $97.5 \pm 2.3$ & \\
\hline & Amino acids $+10^{3} \mu \mathrm{U} / \mathrm{ml}$ insulin & & $47.2 \pm 3.0$ & \\
\hline \multirow[t]{2}{*}{ Chronic acidosis (6) } & Amino acids & $120.8 \pm 2.5 \ddagger$ & & \\
\hline & Amino acids $+10^{3} \mu \mathrm{U} / \mathrm{ml}$ insulin & $72.3 \pm 2.8 \ddagger$ & & \\
\hline \multirow[t]{2}{*}{ Indomethacin (9) } & $3 \mu \mathrm{M}$ indomethacin & & $137.9 \pm 3.6$ & \\
\hline & $3 \mu \mathrm{M}$ indomethacin $+10^{3} \mu \mathrm{U} / \mathrm{ml}$ insulin & & $89.5 \pm 4.9$ & \\
\hline Indomethacin & $3 \mu \mathrm{M}$ indomethacin & $176.8 \pm 18.1$ & & \\
\hline + chronic acidosis $(8)$ & $3 \mu \mathrm{U} / \mathrm{ml}$ insulin $+10^{3} \mu \mathrm{U} / \mathrm{ml}$ insulin & $132.9 \pm 17.0^{*}$ & & \\
\hline
\end{tabular}

Values are mean \pm standard error of the mean with the numbers of rats studied indicated in parentheses. Muscles are incubated in Krebs-Henseleit buffer containing $10 \mathrm{mM}$ glucose supplemented with insulin, amino acids, and indomethacin as indicated. By paired comparison, the pH of the media did not affect net protein degradation in muscles of untreated or acidotic rats. ${ }^{*} P<0.05 . \quad ¥ P<0.01$ by unpaired analysis compared to muscles of rats in the respective nonacidotic control group.

ied by incubating muscles from control and acidotic animals in the presence or absence of $3 \mu \mathrm{M}$ indomethacin. This concentration inhibits $\mathrm{PGE}_{2}$ release from incubated muscle by $87 \%$ (26). Indomethacin reduced the rate of net PD in muscles from both groups of rats by a comparable degree (Table V), but it did not correct the accelerated PD associated with chronic metabolic acidosis. In another experiment, rats were given $3 \mathrm{mg}$ of indomethacin $/ \mathrm{kg}$ by gavage twice daily throughout the period of study and $3 \mu \mathrm{M}$ indomethacin was added to the preincubation and incubation media. Despite this regimen, muscles from acidotic rats still had a significantly higher rate of net PD than their controls (Table II). These results indicate that the increased muscle proteolysis of acidosis does not depend upon prostaglandin production.

Table III. Effects of Acidosis on Tissue Levels of ATP and Creatine Phosphate

\begin{tabular}{llllll}
\hline & ATP & & & \multicolumn{2}{l}{ Creatine phosphate } \\
\cline { 2 - 3 } \cline { 5 - 6 } & Basal & $\begin{array}{l}10^{3} \mu \mathrm{U} / \mathrm{ml} \\
\text { insulin }\end{array}$ & & Basal & $\begin{array}{l}10^{3} \mu \mathrm{U} / \mathrm{ml} \\
\text { insulin }\end{array}$ \\
\hline & $\mu \mathrm{mol} / \mathrm{g}$ & $\mu \mathrm{mol} / \mathrm{g}$ & $\mu \mathrm{mol} / \mathrm{g}$ & $\mu \mathrm{mol} / \mathrm{g}$ \\
Control & $5.95 \pm 0.97$ & $5.36 \pm 0.38$ & & $16.02 \pm 0.87$ & $16.49 \pm 0.94$ \\
Acidosis & $6.23 \pm 0.63$ & $6.68 \pm 0.86$ & & $17.86 \pm 1.48$ & $16.49 \pm 0.94$
\end{tabular}

Values are the mean \pm standard error of the mean from muscles from seven acidotic or seven control rats. Rats were gavage-fed the control or $\mathrm{NH}_{4} \mathrm{Cl}$-supplemented $(4 \mu \mathrm{mol} / 100 \mathrm{~g}$ weight per day) diet and the muscles were incubated in Krebs-Henseleit buffer at pH 7.4 (control) or $\mathrm{pH} 7.1$ (acidosis) plus $10 \mathrm{mM}$ glucose without (basal) or with $10^{3}$ $\mu \mathrm{U} / \mathrm{ml}$ insulin.
The possibility that adrenal hormones are important for the catabolic effect of acidosis was examined by comparing rates of $\mathrm{PS}$ and net $\mathrm{PD}$ in muscles of $\mathrm{ADX}$ rats (group $\mathrm{A}$ ), $\mathrm{ADX}$ rats supplemented with a low (group B) or a high physiologic dose of dexamethasone (group $\mathrm{C}$ ). One muscle from each animal in groups B and C was incubated in pH 7.15 media, and the con-

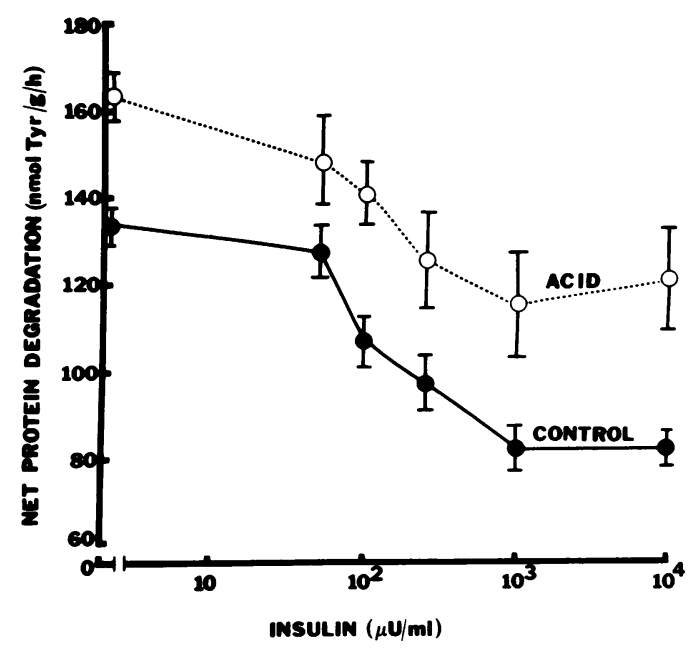

Figure 2. The dose-response relationship between insulin and net protein degradation in muscles incubated for $2 \mathrm{~h}$ in Krebs-Henseleit bicarbonate buffer, $10 \mathrm{mM}$ glucose, $0.2 \mathrm{~g} / \mathrm{dl}$ albumin, and different concentrations of insulin. Muscles from control rats were incubated at $\mathrm{pH}$ 7.40 and muscles from acidotic rats were incubated at $\mathrm{pH} 7.15$. Net protein degradation was measured as tyrosine released into the media. Values at each concentration of insulin are the mean \pm standard error of the mean from muscles of at least six acidotic or six control rats. Differences are significant at each insulin concentration $(P<0.05)$. 
Table IV. Effects of Chronic Metabolic Acidosis on Net Protein Degradation in Incubated Muscle

\begin{tabular}{llc}
\hline & \multicolumn{2}{l}{ Net protein degradation } \\
\cline { 2 - 3 } Treatment & $10^{2} \mu \mathrm{U} / \mathrm{ml}$ insulin & $10^{3} \mu \mathrm{U} / \mathrm{ml}$ insulin \\
\hline & $n m o l$ tyrosine/g per $h$ & $n$ mol tyrosine $/ g$ per $h$ \\
& $107.6 \pm 5.3$ & $81.0 \pm 4.3$ \\
Control (14) & $141.6 \pm 7.3 \ddagger$ & $116.0 \pm 12.6^{*}$ \\
$\mathrm{NH}_{4} \mathrm{Cl}(12)$ & $120.9 \pm 3.3^{*}$ & $98.2 \pm 3.9 \ddagger$ \\
$\mathrm{HCl}(10)$ & $99.5 \pm 11.7$ & $81.0 \pm 7.1$ \\
$\mathrm{NH}_{4}$ acetate (6) & &
\end{tabular}

Values are mean \pm standard error of the mean with the number of rats studied indicated in parentheses. Muscles were incubated in media containing $10^{2}$ or $10^{3} \mu \mathrm{U} / \mathrm{ml}$ as indicated.

$* P<0.05$.

$\ddagger P<0.01$ compared to values obtained from muscles of control rats.

tralateral muscle was incubated in $\mathrm{pH} 7.4$ media. As expected $(15,17)$, a high physiologic dose of glucocorticoids depressed PS compared to the low dose or unsupplemented ADX rats (Table VI). Within each group, there was no significant difference in muscle PS between control and acidotic rats. Importantly, acidosis did not increase net PD in muscles of unsupplemented ADX rats. Net PD in muscles of acidotic, ADX rats treated with low-dose dexamethasone (group B) was increased when compared to nonacidotic control muscles. This is consistent with the interpretation that even a low level of glucocorticoids will permit expression of the proteolytic effect of acidosis. However, net $P D$ in the nonacidotic, control muscles of group $B$ rats was slightly less than that in muscles of unsupplemented, ADX rats (group A). Therefore, the findings in muscles of group B rats could be due to inhibition of PD in the control group rather than an increase in proteolysis in the acidotic group. The interaction between glucocorticoids and acidosis was clarified in the studies of ADX rats given higher doses of dexamethasone (group C). Net PD in muscles of group C control rats (Table VI) was the same as that of acidotic and nonacidotic, unsupplemented ADX (group A) or intact, control rats (Fig. 2). In sharp contrast, net $\mathrm{PD}$ in muscles of chronically acidotic group $\mathrm{C}$ rats was high and indistinguishable from that of intact acidotic rats (Fig. 2). Because these results suggest that the proteolytic effect of acidosis in muscle requires a high glucocorticoid level, we measured the 24-h corticosterone excretion rates of intact control and acidotic rats. As shown in Fig. 3, acidotic rats excreted more corticosterone on the average $(6.4 \pm 0.9$, acid vs. $3.4 \pm 0.5 \mathrm{~g}$ corticosterone/ $\mathrm{kg} \cdot \mathrm{d} ; P<0.02)$, though values for the two groups overlapped.

Results from experiments using pH 7.40 and pH 7.15 media also emphasize the importance of glucocorticoids in the proteolytic response to acidosis. Muscles of 18 nonacidotic ADX rats treated with $3 \mu \mathrm{g} / 100 \mathrm{~g}$ dexamethasone twice daily (group C, control) exhibited accelerated proteolysis when incubated at $\mathrm{pH}$ 7.15. In a paired experiment, net $\mathrm{PD}$ of muscles incubated at pH 7.15 was significantly $(P<0.001)$ higher than that of the contralateral muscle incubated at $\mathrm{pH} 7.40$ (Table VI). A proteolytic response to acute acidosis was not observed during incubation of muscles of nonacidotic, intact group A or group B rats (Table VI).

Chronic metabolic acidosis did not stimulate muscle glutamine production $(3.18 \pm 0.38$, acid vs. $3.03 \pm 0.17 \mu \mathrm{mol} / \mathrm{g} \cdot \mathrm{h}$, control) even though net PD was higher (Table II). Likewise, acidosis did not cause a significant rise in the aortic-inferior vena caval difference in whole blood glutamine. When rats were given $\mathrm{HCl}$ (study II) and compared to control rats, the arteriovenous glutamine differences across the hindquarter were $+38 \pm 33$, acid and $-52 \pm 54 \mu \mathrm{M}$, control).

\section{Discussion}

Although previous reports have documented impaired growth in acidotic rats (42), the metabolic consequences of chronic acidosis have not been delineated. In rats fed isonitrogenous diets, we have established that acidosis increases total urinary nitrogen without changing net urea production (Table I). Because growth was impaired while urea production was unchanged, the increased nitrogen excretion must mean that acidotic rats have impaired nitrogen utilization. We found that the catabolic effect of acidosis extends to skeletal muscle protein. Because PS was unaffected by acidosis (see above), the increase in net PD in muscle (Fig. 2) must have been caused by stimulation of proteolysis. Acute exposure to an acidified perfusate or incubation media alone did not stimulate proteolysis in muscle, even though sufficient time (30 min) was allotted for equilibration of the intracellular $\mathrm{pH}$ at a new steady-state value (43). Moreover, muscle proteolysis in ADX, chronically acidotic rats was not increased despite an acidosis of both a degree and duration comparable to that of intact, acidotic rats. Finally, the increase in muscle PD induced by chronic acidosis was not reversed by incubating at $\mathrm{pH}$ 7.40. This indicates that the abnormalities in protein turnover are not responsive to an acute rise in extracellular and presumably intracellular pH (43).

- In muscle, PD is mediated by lysosomal and cytoplasmic proteolytic pathways, but the factors controlling flux through these pathways are unknown $(44,45)$. Because EP475, at doses known to inhibit lysosomal cathepsin B, H, and L activity (19, 26) did not correct the increased net $P D$ in muscles of acidotic rats, it is likely that the excessive proteolysis of chronic acidosis occurs through nonlysosomal pathways (20). This assumes that most of the important lysosomal proteases were inhibited in this experiment. In addition, the accelerated proteolysis is not dependent on $\mathrm{PGE}_{2}$ synthesis since indomethacin, at doses suffi-

Table V. Effects of Indomethacin and Inhibition of Lysosomal Thiol Proteases on Net Protein Degradation in Incubated Muscles

\begin{tabular}{|c|c|c|c|c|c|c|}
\hline \multirow[b]{2}{*}{ Addition } & \multicolumn{3}{|l|}{ Control } & \multicolumn{3}{|l|}{ Acidotic } \\
\hline & No addition & Addition & \% Change & No addition & Addition & \% Change \\
\hline EP $475(25 \mu \mathrm{M})$ & $138.92 \pm 8.2$ & $120.6 \pm 5.9$ & $9.2 \pm 5.6$ & $171.4 \pm 9.3$ & $152.6 \pm 10.8$ & $8.1 \pm 3.7$ \\
\hline Indomethacin $(3 \mu \mathrm{M})$ & $142.8 \pm 4.4$ & $132.4 \pm 2.1$ & $6.8 \pm 3.5$ & $171.5 \pm 9.4$ & $152.3 \pm 5.3$ & $8.9 \pm 2.4$ \\
\hline
\end{tabular}


Table VI. Interaction between Metabolic Acidosis and Dexamethasone on the Components of Muscle Protein Turnover

\begin{tabular}{|c|c|c|c|c|c|}
\hline & & \multicolumn{2}{|c|}{ Protein synthesis } & \multicolumn{2}{|c|}{ Net protein degradation } \\
\hline & & $\begin{array}{l}\mathrm{pH} 7.15 \\
\text { Media }\end{array}$ & $\begin{array}{l}\text { pH } 7.40 \\
\text { Media }\end{array}$ & $\begin{array}{l}\text { pH } 7.15 \\
\text { Media }\end{array}$ & pH 7.40 Media \\
\hline & . & \multicolumn{2}{|c|}{ nmol phenylalanine/g per $h$} & \multicolumn{2}{|c|}{ nmol tyrosine/g per $h$} \\
\hline \multirow[t]{2}{*}{ Adrenalectomy } & Control & ND & $38.3 \pm 2.1$ & ND & $133.3 \pm 2.6$ \\
\hline & Acidotic & $43.9 \pm 2.2$ & ND & $138.4 \pm 3.8$ & ND \\
\hline \multirow{2}{*}{$\begin{array}{l}\text { Adrenalectomy }+ \text { dexamethasone } \\
(0.6 \mu \mathrm{g} / 100 \mathrm{~g} \text {, twice daily })\end{array}$} & Control & $44.4 \pm 2.2$ & $43.0 \pm 3.9$ & $125.4 \pm 3.7$ & $126.9 \pm 3.9$ \\
\hline & Acidotic & $46.1 \pm 1.9$ & $48.8 \pm 1.4$ & $139.5 \pm 3.4 \ddagger$ & $143.7 \pm 3.1 \ddagger$ \\
\hline \multirow{2}{*}{$\begin{array}{l}\text { Adrenalectomy }+ \text { dexamethasone } \\
(3 \mu \mathrm{g} / 100 \mathrm{~g} \text {, twice daily })\end{array}$} & Control & $34.2 \pm 1.4 \S$ & $35.2 \pm 1.8 \S$ & $152.6 \pm 5.3 \S$ & $135.6 \pm 4.9 * \S$ \\
\hline & Acidotic & $32.8 \pm 1.5 \S$ & $33.7 \pm 1.4 \S$ & $156.2 \pm 4.2 \S$ & $159.8 \pm 5.3 \ddagger \S$ \\
\hline
\end{tabular}

Values are mean \pm standard error of the mean for control and acidotic rats gavage-fed the control diet or the $\mathrm{NH}_{4} \mathrm{Cl}$-supplemented diet for $5 \mathrm{~d}$. Protein synthesis was measured in muscles of six or more rats in each group. Net protein degradation was measured in muscles of 11 or more rats in each group. For each group, except unsupplemented, ADX rats, one muscle was incubated at $\mathrm{pH} 7.15$ and the contralateral muscle at $\mathrm{pH} 7.40$ for paired analysis. ND, not determined. ${ }^{*} P<0.01$ by paired $t$ test. $\ddagger P<0.05$ by unpaired $t$ test compared to control rats treated with the same dose of dexamethasone. $\S P<0.05$ compared to rats treated with $0.6 \mu \mathrm{g} / 100 \mathrm{~g}$ dexamethasone twice daily (analysis of variance).

cient to block prostaglandin synthesis $(20,26)$, did not correct the abnormal protein turnover.

Despite an increase in proteolysis, glutamine production by muscle was not increased by chronic acidosis, confirming previous reports (7-9). Because muscle can convert certain amino acids to glutamine $(10,46)$, the increase in PD would be expected to stimulate glutamine production. Consequently, our results and those of others (7-9) suggest that acidosis lowers glutamine synthesis in muscle. It is unlikely that substrate availability could have limited glutamine synthesis because muscles were incubated in media containing ammonium and amino acids, and tissue glutamate levels were the same for both acid and control muscles. This finding contrasts with the report of Schrock and Goldstein who found that the arteriovenous glutamine difference across

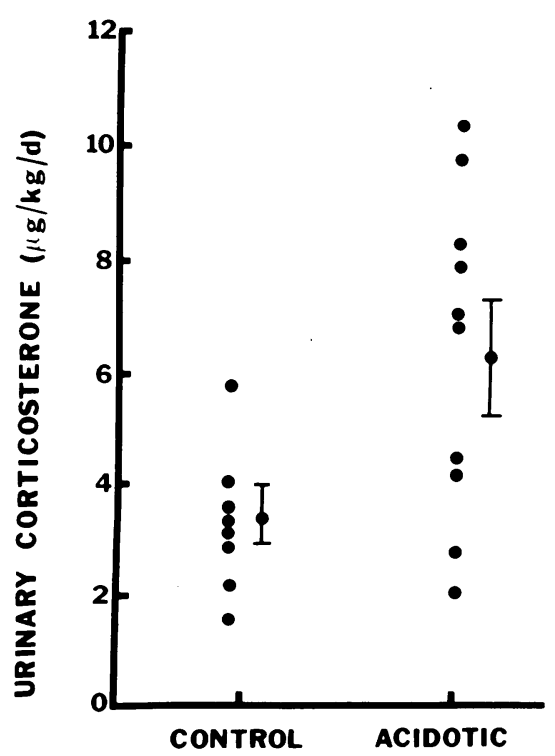

Figure 3. Urinary free corticosterone values of individual rats. Acidotic rats were gavage-fed a diet supplemented with $4 \mathrm{mmol} \mathrm{NH}_{4} \mathrm{Cl}$ / $100 \mathrm{~g}$ of body weight per day. Mean values were significantly different $(P<0.05)$. hindlimbs of chronically acidotic rats was increased (5). In that study, the rats were not pair-fed and it is possible that decreased food intake by the acidotic rats caused the difference since starvation increases glutamine efflux from peripheral tissues (46).

Several reports have documented the importance of glucocorticoids in the renal response to metabolic acidosis. In ADX rats, there is impaired renal glutamine uptake and ammoniagenesis in response to acidosis (47), and increasing doses of glucocorticoids raise ammonia excretion (48). We have extended the report (12) that acidosis raises plasma corticosterone by showing that corticosterone production, as reflected in its 24-h urinary excretion, is stimulated by acidosis (Fig. 3). Urinary corticosterone excretion by rats also rises with other stresses (49) and more accurately estimates corticosterone production than a single plasma level which can increase in response to blood sampling or anesthesia (50). Because other factors that affect corticosterone production in small rodents, such as handling, feeding schedules, and ambient temperature (51), were the same for both control and acidotic rats, we conclude that the higher corticosterone excretion in the acidotic group must have been caused by the acidosis.

The present study elucidates a new mechanism by which adrenal glucocorticoids coordinate the response to metabolic acidosis. Glucocorticoids are necessary for the increased muscle proteolysis of acidosis. This conclusion was reached because proteolysis was not stimulated in muscles from chronically acidotic, ADX rats and because the increase in PD was restored (Table VI) in ADX rats supplemented with dexamethasone at doses calculated to achieve plasma glucocorticoid levels in stressed rats. Dexamethasone was used in these experiments because its long half-life provides a consistent glucocorticoid effect throughout the day (22). The proteolytic response to acidosis in ADX animals treated with $3 \mu \mathrm{g}$ of dexamethasone/100 $\mathrm{g}$ of weight twice daily was not due to a nonspecific or pharmacologic effect of this synthetic steroid because neither PD nor PS in muscles of nonacidotic rats in this group were different from values measured in muscles of nonacidotic, intact rats (Table VI; Fig. 2).

Generally, glucocorticoids affect muscle protein turnover by inhibiting PS (15-17). Increased PD, in response to glucocor- 
ticoids, has only been noted in starved, immature rats (14). Consequently, it was interesting that proteolysis increased rapidly when muscle from mature, nonacidotic, dexamethasone-treated ADX rats were incubated in acidic media (Table VI). This indicates that glucocorticoids can prime proteolytic pathways to respond to an acute stress in certain catabolic conditions.

These results suggest that skeletal muscle shares in the metabolic response to acidosis by providing nitrogen for renal ammoniagenesis. Although the primary source for glutamine that is extracted by the kidney remains undefined, we found no evidence for increased glutamine release by muscle. Other possibilities include increased hepatic glutamine synthesis $(52,53)$ or decreased glutamine utilization by small intestinal epithelia. In response to other catabolic stimuli, increased amino acid release from muscle results in a proportionate rise in hepatic urea synthesis $(28,54)$. In contrast, acidosis did not increase urea production despite increased release of amino acids from muscle (Table I). Thus, amino acids released from muscle could be used by the liver to synthesize glutamine. In fact, several groups have found that acidosis stimulates hepatic glutamine synthesis in rats $(52,53,55)$. If inhibition of intestinal glutamine utilization during acidosis provided the sole source of extra glutamine for the kidney, urea synthesis should have risen when muscle proteolysis increased, but this did not occur. Moreover, studies of intestinal glutamine utilization in chronically acidotic rats, including incubated intestinal segments (56), the isolated perfused intestine (57), the arteriovenous glutamine flux across the intestine (5), and incubation of intestinal epithelial cells (58), have found no evidence for inhibition of intestinal glutamine utilization. Therefore, we conclude that proteolysis is increased in skeletal muscle in chronic metabolic acidosis, and that it is mediated, in part, by a rise in glucocorticoid secretion. We propose that mobilization of amino acids from muscle is an important physiologic response to chronic acidosis because it provides amino acid nitrogen for hepatic glutamine production and subsequent renal ammoniagenesis.

\section{Acknowledgments}

We would like to thank Dr. Richard Underwood of the Division of Endocrinology-Hypertension of Brigham and Women's Hospital for his help and advice with the corticosterone assay. We wish to thank Georgia Karapanos for technical assistance and Paula Dolan for expert editorial assistance.

This study was supported by grants AM-26903 and AM-07131 from the National Institutes of Health and a Clinician-Scientist Award (to Dr. Kelly) from the American Heart Association.

\section{References}

1. Hannaford, M. C., M. B. Goldstein, R. G. Josse, and M. L. Halperin. 1982. Role of acidosis in the protein wasting of fasting in the rat and the rabbit. Can. J. Physiol. Pharmacol. 60:331-334.

2. Hannaford, M. C., L. A. Leiter, R. G. Josse, M. B. Goldstein, E. B. Marliss, and M. L. Halperin. 1982. Protein wasting due to acidosis of prolonged fasting. Am. J. Physiol. 243:E251-E256.

3. Papadoyannakis, N. J., C. J. Stefanidis, and M. McGeown. 1984. The effect of the correction of metabolic acidosis on nitrogen and potassium balance of patients with chronic renal failure. Am. J. Clin. Nutr. 40:623-627.

4. Nash, M. A., A. D. Tourado, I. Greifer, A. Spitzer, and C. M. Edelmann, Jr. 1972. Renal tubular acidosis in infants and children. $J$. Pediatr. 80:738-748.

5. Schrock, H., and L. Goldstein. 1981. Interorgan relationships for glutamine metabolism in normal and acidotic rats. Am. J. Physiol. 240: E519-E525.

6. Schrock, H., C. J. M. Cha, and L. Goldstein. 1980. Glutamine release from hindlimb and uptake by kidney in the acutely acidotic rat. Biochem. J. 188:557-560.

7. Addae, S. K., and W. D. Lotspeich. 1968. Relation between glutamine utilization and production in metabolic acidosis. Am. J. Physiol. 215:269-277.

8. Lund, P., and M. Watford. 1976. Glutamine as a precursor of urea. In The Urea Cycle. S. Grisolia, R. Baguena, and F. Mayor. WileyInterscience, New York. pp. 479-488.

9. Lemieux, G., M. Watford, P. Vinay, and A. Gougoux. 1980. Metabolic changes in skeletal muscle during chronic metabolic acidosis. Int. J. Biochem. 12:75-83.

10. Chang, T. W., and A. L. Goldberg. 1978. The metabolic fates of amino acids and the formation of glutamine in skeletal muscle. J. Biol. Chem. 253:3685-3695.

11. Garber, A. J., I. E. Karl, and D. M. Kipnis. 1976. Alanine and glutamine synthesis and release from skeletal muscle. I. Glycolysis and amino acid release. J. Biol. Chem. 251:826-835.

12. Welbourne, T. C. 1976. Acidosis activation of the pituitary-adrenal-renal glutaminase I axis. Endocrinology. 99:1071-1079.

13. Goldberg, A. L. 1969. Protein turnover in skeletal muscle. II. Effect of denervation and cortisone on protein catabolism in skeletal muscle. J. Biol. Chem. 244:3223-3229.

14. Goldberg, A. L., M. Tischler, G. DeMartino, and G. Griffin. 1980. Hormonal regulation of protein degradation and synthesis in skeletal muscle. Fed. Proc. 39:31-36.

15. Rannels, S. R., and L. S. Jefferson. 1980. Effects of glucocorticoids on muscle protein turnover in perfused rat hemicorpus. Am. J. Physiol. 238:E564-E572.

16. Tomas, F. M., A. J. Murray, and L. M. Jones. 1984. Interactive effects of insulin and corticosterone on myofibrillar protein turnover in rats as determined by $\mathrm{N}$-methylhistidine excretion. Biochem. J. 220: 469-479.

17. Tomas, F. M., H. N. Munro, and V. R. Young. 1979. Effect of glucocorticoid administration and the rate of muscle protein breakdown in vivo in rats, as measured by urinary excretion of $N$-methylhistidine. Biochem. J. 178:139-146.

18. Jones, E. R., T. R. Beck, S. Kapoor, R. Sharp, and R. G. Narins. 1984. Prostaglandins inhibit renal ammoniagenesis in the rat. J. Clin. Invest. 74:992-1002.

19. Rodemann, H. P., and A. L. Goldberg. 1982. Arachidonic acid, prostaglandin $E_{2}$ and $F_{2}$ influence rates of protein turnover in skeletal and cardiac muscle. J. Biol. Chem. 257:1632-1638.

20. Rodemann, H. P., L. Waxman, and A. L. Goldberg. 1982. The stimulation of protein degradation in muscle by $\mathrm{Ca}^{2+}$ is inhibited by prostaglandin $\mathrm{E}_{2}$ and does not require the calcium-activated protease. $J$. Biol. Chem. 257:8716-8723.

21. Slusher, M. A., and S. Roberts. 1957. Fate of adrenal ascorbic acid: Relationship to corticosteroid secretion. Endocrinology. 61:98-105.

22. Dubrovsky, A. H. E., R. C. Nair, M. K. Byers, and D. Z. Levine. 1981. Renal net acid excretion in the adrenalectomized rat. Kidney Int. 19:516-528.

23. Ringler, I., K. West, W. E. Dulin, and E. W. Boland. 1964. Biological potencies of chemically modified adrenocorticosteroids in rat and man. Metab. Clin. Exp. 13:37-44.

24. Sartorius, O. W., D. Calhoon, and R. F. Pitts. 1952. The capacity of the adrenalectomized rat to secrete hydrogen and ammonium ions. Endocrinology. 51:444-450.

25. Ogiso, T., M. Iwaki, and E. Tamaki. 1982. Disposition, intestinal absorption and drug metabolizing enzyme activities after multiple doses of indomethacin in rat and effect of antacid and dicyclomine on the parameters. J. Pharmacol. Dyn. 5:760-770.

26. Clark, A. S., R. A. Kelly, and W. E. Mitch. 1984. Systemic response to thermal injury in rats. J. Clin. Invest. 74:888-897.

27. Peters, J. P., and D. D. Van Slyke. 1932. Quantitative Clinical Chemistry. Vol. II. Williams \& Wilkins, Baltimore, MD. pp. 516-538. 
28. Mitch, W. E. 1981. Amino acid release from the hindquarter and urea appearance in acute uremia. Am. J. Physiol. 241:E415-E419.

29. Clark, A. S., and W. E. Mitch. 1983. Comparisons of protein synthesis and degradation in incubated and perfused muscle. Biochem. J. 212:649-653.

30. Clark, A. S., and W. E. Mitch. 1983. Muscle protein turnover and glucose uptake in acutely uremic rats. $J$. Clin. Invest. 72:836-845.

31. Ruderman, N. B., C. R. S. Houghton, and R. Hems. 1971. Evaluation of the isolated perfused rat hindquarter for the study of muscle metabolism. Biochem. J. 124:639-651.

32. May, R. C., A. S. Clark, A. Goheer, and W. E. Mitch. 1985. Identification of specific defects in insulin-mediated muscle metabolism in acute uremia. Kidney Int. 28:490-497.

33. Waalkes, T. P., and S. Udenfried. 1957. A fluorometric method for the estimation of tyrosine in plasma and tissues. J. Lab. Clin. Med. 50:733-736.

34. Andrews, T. M., R. Goldthorp, and R. E. Watts. 1973. Fluorometric measurements of the physiologic content of human granulocytes. Clin. Chem. Acta. 43:379-387.

35. Lund, P. 1974. Proteins, peptides and amino acids: L-glutamine. In Methods of Enzymatic Analysis. H. U. Bergmeyer, editor. Academic Press, New York. pp. 1719-1722.

36. Lamprecht, W., P. Stein, F. Stein, F. Heinz, and H. Weisser. 1974. Proteins, peptides, and amino acids: creatine phosphate. In Methods of Enzymatic Analysis. H. U. Bergmeyer, editor. Academic Press, New York. pp. 1777-1781.

37. Lamprecht, W., and I. Trautchold. 1974. Nucleic acids: pyrines, pyramines, nucleosides, coenzymes and related compounds: ATP. In Methods of Enzymatic Analysis. H. U. Bergmeyer, editor. Academic Press, New York. pp. 2097-2110.

38. Flugel-Link, R. M., I. B. Salusky, M. R. Jones, and J. D. Kopple. 1983. Protein and amino acid metabolism in posterior hemicorpus of acutely uremic rats. Am. J. Physiol. 244:E615-E623.

39. Hanada, K., M. Tamai, T. Adachi, K. Oguna, K. Koshinagi, S. Ohmura, E. Kominami, T. Towatri, and N. Katunuma. 1983. Characterization of the three new analogs of E-64 and their therapeutic application. In Protein Inhibitors: Medical and Biological Aspects. N. Katunuma, et al., editors. Japan SciSoc Press, Tokyo. pp. 25-36.

40. Oliver, J., and E. Bourke. 1975. Adaptations in urea ammonium excretion in metabolic acidosis in the rat: a reinterpretation. Clin. Sci. Mol. Med. 48:515-520.

41. Clark, A. S., J. M. Fagan, and W. E. Mitch. 1985. Selectivity of the insulin-like actions of vanadate on glucose and protein metabolism in skeletal muscle. Biochem. J. In Press.

42. Cooke, R. E., D. G. Boyden, and E. Haller. 1960. The relationship of acidosis and growth retardation. J. Pediatr. 57:326-337.
43. Aickin, C. C., and R. C. Thomas. 1977. Micro-electrode measurement of the intracellular $\mathrm{pH}$ and buffering power of mouse soleus muscle fibers. J. Physiol. (Lond.). 267:791-810.

44. Goldberg, A. L., and A. C. St. John. 1976. Intracellular protein degradation in mammalian and bacterial cells. Annu. Rev. Biochem. 45: 747-803.

45. Mitch, W. E., and A. S. Clark. 1983. Muscle protein turnover in uremia. Kidney Int. 24(Suppl. 16):S2-S8.

46. Ruderman, N. B., and M. Berger. 1974. The formation of glutamine and alanine in skeletal muscle. J. Biol. Chem. 249:5500-5506.

47. Hughey, R. P., B. B. Rankin, and N. P. Curthoys. 1980. Acute acidosis and renal arteriovenous differences of glutamine in normal and adrenalectomized rats. Am. J. Physiol. 238:F199-F204.

48. Wilcox, C. S., D. Cemerikic, and G. Giebisch. 1982. Differential effects of acute mineralo- and glucocorticoid administration on renal acid elimination. Kidney Int. 21:546-556.

49. Kley, H. K., W. Elsasser, H. Dehnen, and H. L. Kruskemper. 1978. Evaluation of adrenal function in rats by the measurement of urinary free corticosterone, free aldosterone, and free 11-deoxycorticosterone. Steroids. 32:223-232.

50. Carney, J. A., and B. L. Walker. 1973. Mode of killing and plasma corticosterone concentrations in the rat. Lab. Anim. Sci. 23:675-676.

51. Zimmermann, E., and V. Critchlow. 1967. Effects of diurnal variation in plasma corticosterone levels on adrenocortical response to stress. Proc. Soc. Exp. Biol. Med. 125:658.

52. Kinlen, D. M., and E. Bourke. 1975. Effects of chronic metabolic acidosis on glutamine turnover and urea production in the perfused rat liver. Isr. J. Med. Sci. 144:453-462.

53. Lueck, J. D., and L. L. Miller. 1970. The effect of perfusate pH on glutamine metabolism in the isolated perfused rat liver. J. Biol. Chem. 245:5491-5497.

54. Walser, M. 1980. Determinants of ureagenesis, with particular reference to renal failure. Kidney Int. 17:709-721.

55. Haussinger, D., W. Gerok, and H. Sies. 1983. Regulation of flux through glutaminase and glutamine synthetase in isolated perfused rat liver. Biochim. Biophys. Acta. 755:272-278.

56. McFarlane-Anderson, N., F. I. Bennett, and G. A. O. Alleyne. 1976. Ammonia production by the small intestine of the rat. Biochim. Biophys. Acta. 437:238-243.

57. Hanson, P. J., and D. S. Parsons. 1977. Metabolism and transport of glutamine and glucose in vascularly perfused small intestine rat. Biochem. J. 166:509-520.

58. Pinkus, L. M., and H. G. Windmueller. 1977. Phosphate-dependent glutaminase of small intestine: Localization and role in intestinal glutamine metabolism. Arch. Biochem. Biophys. 182:506-517. 